\title{
Do nurses or doctors have an increased risk of developing multiple sclerosis?
}

\author{
Geoffrey Dean, Richard Gray
}

\begin{abstract}
A cluster of multiple sclerosis (MS) patients has been reported in seven of 307 nurses in Key West, Florida. The MS death rates in British nurses and qualified medical practitioners were looked at and no increased mortality from multiple sclerosis was found. Neither was there an increase in mortality from motor neuron disease (amyotrophic lateral sclerosis), the control disease. Death rates from MS vary with social class, being highest in social class IIIN (skilled non-manual) and lowest in social class II (intermediate). These different rates may be due to $M S$ causing health related occupational mobility. Allowance for the inter-class variability in MS death rates did not materially affect the conclusion that death from MS appears to be no more common than expected among nurses and doctors than in the general population. Possible explanations for the cluster of multiple sclerosis among nurses in Key West are discussed.
\end{abstract}

A high prevalence of multiple sclerosis (MS) has been reported in Key West, Florida. This was previously considered a low MS prevalance area. ${ }^{12}$ Nurses working in the area had a particularly high MS prevalence, seven out of 307 nurses. Increased rates in medical personnel would provide indirect support for the hypothesis that MS is caused by an exogenous factor which may be transmissible. It could also cause anxiety among nurses that they may be in danger of "catching" $M S$ from MS patients. We have therefore undertaken a study to discover if there is an increased risk of death being reported as due to $M S$, or motor neuron disease (MND) as a control disease, among nurses and nursing administrators and among medical practitioners. We also studied social class differences that may occur in deaths registered as due to MS.

The Medico-Social Research Board, Dublin

G Dean

Clinical Trial Service Unit and ICRF Cancer Studies Unit, Radcliffe Infirmary, Oxford R Gray

Correspondence to: $\mathrm{Dr}$ Dean, PO Box 1851,
Ballsbridge, Dublin, Ireland. Received 7 July 1989 and in final revised form 18 April

1990.

Accepted 9 May 1990

\section{Method}

A recent study in England showed that in $74 \%$ of patients diagnosed as having MS, the diagnosis was on the death certificate. In $46 \%$ of all the death certificates MS had been mentioned in Part I of the certificate as "an intervening antecedent cause or as an underlying antecedent cause of death" and in $28 \%$ on Part II of the certificate as "another significant" condition contributing to the death, but not relating to the disease or causing it". ${ }^{3}$
Some information on the mortality from MS by occupation and by social class was already available from the studies undertaken by the Office of Population Censuses and Surveys (OPCS) in England and Wales based on the deaths during 1970-72, using the 1971 census, and on the deaths in $1979,1980,1982$ and 1983 using the 1981 census (1981 omitted). ${ }^{45}$ We have added to these studies the three additional years 1984-1986 inclusive. The expected number of deaths was calculated, for each sex and age group, from the rates in the general population. In the 1970-72 survey mortality from MS and MND was analysed by social class, but not by the specific occupations of "qualified medical practitioners" and "nurses and nursing administrators". These occupations were, however, analysed in the later seven-year study. A similar survey took place in Scotland in 1979, 1980, 1982 and $1983 .^{6}$

We also examined the MS and MND death rates among British doctors in the long-term British Doctors' Smoking Study. Detailed methods have been reported previously. ${ }^{78}$ In brief, the population consisted of 34439 male doctors and 6194 female doctors, who were listed in the British Medical Register and who replied to a questionnaire in 1951 about their smoking habits. The male doctors were followed up through regular questionnaires supplemented by the use of national mortality records. The women doctors were followed up by questionnaires until 1973 but not thereafter. By 1987 and 1973 respectively, over $99^{\circ}{ }_{0}$ of the doctors who were not known to be dead had been traced. Underlying cause of death was obtained from the official death certificates and, except for deaths where lung cancer was mentioned, the certified cause was accepted without further enquiry. Expected numbers of deaths were calculated within five year age strata using the mean of the published sex-specific death rates for England and Wales in 1965, 1975 and 1985. Confidence limits for the standardised mortality ratios (SMR) were calculated based on a Poisson distribution ${ }^{9}$

\section{Results}

Nurses and nursing administrators

During the seven years $1979-80$ and $1982-86$ available for study of deaths by occupation in England, Wales and Scotland, there were 55 deaths from MS observed among female nurses and nursing administrators, (52 nurses and three nursing administrators). The expected number allowing for age and sex was 58.4 
Table 1 Multiple Sclerosis reported as the Primary Cause of Death.

Part I of death certificate (All deaths 1979, 1980, 1982-86) Nurses and Nursing Administrators

\begin{tabular}{|c|c|c|c|c|c|c|c|}
\hline & \multicolumn{3}{|c|}{ All Men } & \multicolumn{3}{|c|}{ Married and single women } & \multirow[b]{3}{*}{ Total } \\
\hline & \multicolumn{2}{|c|}{ Age group } & \multirow[b]{2}{*}{ Total } & \multicolumn{2}{|c|}{ Age group } & \multirow[b]{2}{*}{ Total } & \\
\hline & $20-64$ & $65-74$ & & $20-64$ & $65-74$ & & \\
\hline $\begin{array}{l}\text { England and Wales } \\
\text { (except 1981). Seve }\end{array}$ & & & & & & & \\
\hline $\begin{array}{l}\text { Observed deaths } \\
\text { Expected deaths }\end{array}$ & $\begin{array}{l}3 \\
3 \cdot 5\end{array}$ & - & $\begin{array}{l}3 \\
3 \cdot 5\end{array}$ & $\begin{array}{l}31 \\
36 \cdot 8\end{array}$ & $\begin{array}{l}19 \\
15 \cdot 4\end{array}$ & $\begin{array}{l}50 \\
52 \cdot 2\end{array}$ & $\begin{array}{l}53 \\
55 \cdot 7\end{array}$ \\
\hline Scotland 1979, 1980 & & & & & & & \\
\hline $\begin{array}{l}\text { Four years } \\
\text { Observed deaths } \\
\text { Expected deaths }\end{array}$ & $\overline{0.5}$ & $\overline{0 \cdot 1}$ & $\overline{0 \cdot 6}$. & $\begin{array}{l}1 \\
1 \cdot 7\end{array}$ & $\begin{array}{l}1 \\
0 \cdot 4\end{array}$ & $\begin{array}{l}2 \\
2 \cdot 1\end{array}$ & $\begin{array}{l}2 \\
2 \cdot 7\end{array}$ \\
\hline $\begin{array}{l}\text { Total } \\
\text { Observed deaths } \\
\text { Expected deaths }\end{array}$ & $\begin{array}{l}3 \\
4 \cdot 0\end{array}$ & $\overline{0 \cdot 1}$ & $\begin{array}{l}3 \\
4 \cdot 1\end{array}$ & $\begin{array}{l}32 \\
38 \cdot 5\end{array}$ & $\begin{array}{l}20 \\
15 \cdot 8\end{array}$ & $\begin{array}{l}52 \\
54 \cdot 3\end{array}$ & $\begin{array}{l}55 \\
58 \cdot 4\end{array}$ \\
\hline
\end{tabular}

(SMR 0.69 to 1.14 is not a significant difference) (table 1). Multiple sclerosis was mentioned in Part II of the death certificate in a further eight nurses. There were too few male nurses for meaningful analysis.

\section{Qualified medical practitioners}

In the British Doctors' Smoking Study the age-adjusted expected number of deaths from MS was calculated, based on a total of 858555 man-years of follow up of male doctors and 252199 women-years for female doctors. There were 31 observed deaths with MS reported as the primary cause of death (26 males and five females), while the expected number of deaths among the doctors was 26.6 , (table 2). The standardised mortality ratio (SMR) was thus 1.17 with $95 \%$ confidence limits ranging from 0.76 to 1.58 , that is, there was no significant excess of MS deaths. MS was mentioned in Part II of the death certificate in nine additional doctors. There were 42 observed deaths from MND, 41 males and one female, and 37 was the expected number of deaths, again, there was no significant difference between the observed and expected number of deaths and the confidence limits for the SMR ranged from 0.80 to 1.47 .

During the seven years at present available for study for all deaths in England and Wales for medical practitioners, 1979-86 (except for 1981 when the OPCS records of occupation were incomplete), there were nine deaths from MS (part I of the death certificate) among qualified medical practitioners and the agestandardised expected number was $9 \cdot 2$ (SMR 0.34 to 1.61$)$; they were all male. Four of the nine multiple sclerosis deaths were included

Table 2 British Doctors' Smoking Study

\begin{tabular}{|c|c|c|c|c|c|c|c|c|c|}
\hline \multicolumn{5}{|c|}{ Multiple sclerosis reported as the primary cause of death } & \multicolumn{5}{|c|}{ Motor neuron disease reported as the primary cause of death } \\
\hline & \multicolumn{3}{|c|}{ Age group } & \multirow[b]{2}{*}{ All ages } & & \multicolumn{3}{|c|}{ Age group } & \multirow[b]{2}{*}{ All ages } \\
\hline & $20-64$ & $65-74$ & $75+$ & & & $20-64$ & $65-74$ & $75+$ & \\
\hline $\begin{array}{l}\text { Male doctors 1951-1987 } \\
\text { Observed deaths } \\
\text { Expected deaths }^{\star}\end{array}$ & $\begin{array}{l}18 \\
16 \cdot 4\end{array}$ & $\begin{array}{l}7 \\
4.5\end{array}$ & $\begin{array}{l}1 \\
1.6\end{array}$ & $\begin{array}{l}26 \\
22 \cdot 5\end{array}$ & $\begin{array}{l}\text { Male doctors 1951-1987 } \\
\text { Observed deaths } \\
\text { Expected deaths }\end{array}$ & $\begin{array}{l}17 \\
15.6\end{array}$ & $\begin{array}{l}17 \\
12 \cdot 1\end{array}$ & $\begin{array}{l}7 \\
6.8\end{array}$ & $\begin{array}{l}41 \\
34.5\end{array}$ \\
\hline $\begin{array}{l}\text { Female doctors 1951-1973 } \\
\text { Observed deaths } \\
\text { Expected deaths }\end{array}$ & $\begin{array}{l}4 \\
3 \cdot 6\end{array}$ & $\begin{array}{l}1 \\
0.5\end{array}$ & $\begin{array}{l}0 \\
0 \cdot 1\end{array}$ & $\begin{array}{l}5 \\
4 \cdot 1\end{array}$ & $\begin{array}{l}\text { Female doctors 1951-1973 } \\
\text { Observed deaths } \\
\text { Expected deaths }\end{array}$ & $\begin{array}{l}0 \\
1.3\end{array}$ & $\begin{array}{l}1 \\
0.9\end{array}$ & $\begin{array}{l}0 \\
0.3\end{array}$ & $\begin{array}{l}1 \\
2.5\end{array}$ \\
\hline $\begin{array}{l}\text { All doctors } \\
\text { Observed deaths } \\
\text { Expected deaths }\end{array}$ & $\begin{array}{l}22 \\
20 \cdot 0\end{array}$ & $\begin{array}{l}8 \\
5.0\end{array}$ & $\begin{array}{l}1 \\
1.7\end{array}$ & $\begin{array}{l}31 \\
26.6\end{array}$ & $\begin{array}{l}\text { All doctors } \\
\text { Observed deaths } \\
\text { Expected deaths }\end{array}$ & $\begin{array}{l}17 \\
16.9\end{array}$ & $\begin{array}{l}18 \\
13.0\end{array}$ & $\begin{array}{l}7 \\
7 \cdot 1\end{array}$ & $\begin{array}{l}42 \\
37 \cdot 0\end{array}$ \\
\hline
\end{tabular}

*Expected deaths are computed within five year age strata and based on a total of 858555 man-years of follow up of the male doctors and 252199 woman-years for the female doctors.

Table 3 Multiple Sclerosis reported as the Primary Cause of Death.

Part I of death certificate (All deaths 1979, 1980, 1982-86) Qualified medical practitioners

\begin{tabular}{|c|c|c|c|c|c|c|c|}
\hline & \multicolumn{3}{|c|}{ All Men } & \multicolumn{4}{|c|}{ Married and single women } \\
\hline & \multicolumn{2}{|c|}{ Age group } & \multirow[b]{2}{*}{ Total } & \multicolumn{2}{|c|}{ Age group } & \multirow[b]{2}{*}{ Total } & \multirow[b]{2}{*}{ Total } \\
\hline & $20-64$ & $65-74$ & & $20-64$ & $65-74$ & & \\
\hline $\begin{array}{l}\text { England and Wales 1979-1986 } \\
\text { (except 1981). Seven years }\end{array}$ & & & & & & & \\
\hline $\begin{array}{l}\text { Observed deaths } \\
\text { Expected deaths }\end{array}$ & $\begin{array}{l}3 \\
5 \cdot 4\end{array}$ & $\begin{array}{l}1 \\
0.9\end{array}$ & $\begin{array}{l}4 \\
6 \cdot 3\end{array}$ & $\begin{array}{l}1 \\
1 \cdot 6\end{array}$ & $\begin{array}{l}2 \\
0.4\end{array}$ & $\begin{array}{l}3 \\
2 \cdot 0\end{array}$ & $\begin{array}{l}7 \\
8 \cdot 3\end{array}$ \\
\hline $\begin{array}{l}\text { Scotland 1979, 1980, 1982, } 1983 \\
\text { Four years }\end{array}$ & & & & & & & \\
\hline $\begin{array}{l}\text { Four years } \\
\text { Observed deaths } \\
\text { Expected deaths }\end{array}$ & $\begin{array}{l}2 \\
0 \cdot 7\end{array}$ & $\overline{0.1}$ & $\begin{array}{l}2 \\
0.8\end{array}$ & $\overline{0.1}$ & $\overline{0.0}$ & $\overline{0.1}$ & $\begin{array}{l}2 \\
0.9\end{array}$ \\
\hline Total & & & & & & & \\
\hline $\begin{array}{l}\text { Observed deaths } \\
\text { Expected deaths }\end{array}$ & $\begin{array}{l}5 \\
6 \cdot 1\end{array}$ & $\begin{array}{l}1 \\
1 \cdot 0\end{array}$ & $\begin{array}{l}6 \\
7 \cdot 1\end{array}$ & $\begin{array}{l}1 \\
1.7\end{array}$ & $\begin{array}{l}2 \\
0 \cdot 4\end{array}$ & $\begin{array}{l}3 \\
2 \cdot 1\end{array}$ & $\begin{array}{l}9 \\
9 \cdot 2\end{array}$ \\
\hline
\end{tabular}


Table 4 Multiple sclerosis as Underlying Cause by Social Class

Deaths: England and Wales 1970-72, aged 15-64. Great Britain 1979, 1980, 1982, 1983 aged 20-64 men, $20-59$ women and standardised mortality ratios (SMRs)

\begin{tabular}{|c|c|c|c|c|c|c|c|c|c|c|}
\hline & \multirow[b]{2}{*}{ Social Class } & \multicolumn{3}{|l|}{ Men } & \multicolumn{3}{|c|}{ Married and single women } & \multicolumn{3}{|c|}{ All persons } \\
\hline & & Observed & Expected & $S M R^{\star}$ & Observed & Expected & $S M R^{\star}$ & Observed & Expected & $S M R$ \\
\hline \multirow[t]{2}{*}{$\begin{array}{l}\text { I } \\
\text { IIIN } \\
\text { IIIM } \\
\text { IV } \\
\text { V }\end{array}$} & $\begin{array}{l}\text { Professional } \\
\text { Intermediate } \\
\text { Skilled (non-manual) } \\
\text { Skilled (manual) } \\
\text { Partly skilled } \\
\text { Unskilled } \\
\text { Not classified }\end{array}$ & $\begin{array}{r}92 \\
251 \\
251 \\
531 \\
274 \\
116 \\
113\end{array}$ & $\begin{array}{r}77 \cdot 4 \\
312 \cdot 2 \\
167 \cdot 5 \\
551 \cdot 3 \\
281 \cdot 5 \\
116 \cdot 8\end{array}$ & $\begin{array}{l}119 \\
80^{\star \star} \\
150^{\star \star \star} \\
96 \\
97 \\
98\end{array}$ & $\begin{array}{r}110 \\
404 \\
278 \\
588 \\
322 \\
85 \\
120\end{array}$ & $\begin{array}{r}84 \cdot 0 \\
410 \cdot 8 \\
253 \cdot 2 \\
554 \cdot 1 \\
303 \cdot 4 \\
98 \cdot 5\end{array}$ & $\begin{array}{l}131^{\star} \\
98 \\
110 \\
106 \\
106 \\
86\end{array}$ & $\begin{array}{r}202 \\
655 \\
529 \\
1119 \\
596 \\
201 \\
233\end{array}$ & $\begin{array}{r}161 \cdot 4 \\
723 \cdot 0 \\
420 \cdot 7 \\
1105 \cdot 4 \\
584 \cdot 9 \\
215 \cdot 3\end{array}$ & $\begin{array}{r}125 \\
91 \\
126 \\
101 \\
102 \\
93\end{array}$ \\
\hline & & 1628 & & & 1907 & & & 3535 & & \\
\hline
\end{tabular}

${ }^{\star p}$-value; ${ }^{\star}=\mathrm{p}<0.05{ }^{\star \star}=\mathrm{p}<0.001 ;^{\star \star \star}=\mathrm{p}<0.0001$.

in the British Doctors' Smoking Study. There were nine deaths also from motor neuron disease and the age-standardised expected number was 9.1 (SMR 0.34 to 1.61). Again, they were all male and there was no significant difference (table 3 ).

\section{Social Class}

There is considerable heterogeneity in MS death rates between social class and between sexes (table 4). Multiple sclerosis as a cause of death was significantly $(p<0.0001)$ more frequently reported among males in social class IIIN (skilled non-manual), among whom there were a total of 251 deaths in 1970-72 and 1979-83. The expected number was $167 \cdot 5$ ( $\mathrm{SMR}=1.31$ to 1.68 ). The observed number of MS deaths was significantly less than expected in men in social class II (intermediate) 251 deaths and $312 \cdot 2$ expected ( $p<$ 0.001 ) but, again, not in women. To a lesser extent, MS deaths were also greater than expected (SMR $=1.08$ to 1.42 ) among members of either sex in social class I (professional). However, when correction is made for social class, there is still no material difference between the observed and expected number of deaths from multiple sclerosis among nurses and doctors.

\section{Discussion}

This is a large set of data on MS in medical personnel. In total, there were $31 \mathrm{MS}$ deaths in the British Doctors' Smoking Study and 55 among the nurses and nursing administrators, giving a total of 86 deaths with 89.0 expected. The SMR is thus 0.97 with $95 \%$ confidence limits of 0.76 to $1 \cdot 17$. There was some overlap between the census data and the Doctors' Smoking Study and so the census data are ignored. Therefore, unless some substantial source of bias exists, these data preclude anything but a very small increase in MS risk among medical personnel compared with the general population.

What biases could there be in these data analyses? It is very unlikely that nurses and doctors, if they have MS or MND, would be less likely to have the diagnosis on the death certificate than the general population. If anything, the reverse would be expected. National MS death rates did not vary appreciably during the period of the Doctors' Smoking Study. Thus, taking an average of the MS rates for
1965,1975 and $1985^{10-12}$ is unlikely to have introduced any material bias into the calculation of expected numbers. Further, the use of crude death rates, as opposed to those for social class I (professional), is likely to have slightly underestimated the expected number of MS deaths. Again, this cannot explain the apparent lack of any increased risk of doctors developing MS in this study.

One possible source of bias arises when the striking variability in certified MS death rates between social classes is considered. It may well be that the progressively disabling nature of the disease results in health-related occupational mobility, and thus the occupation that is listed on the death certificate may not be the same as the occupation when the disease was diagnosed. It has been reported previously that $50 \%$ of MS sufferers give up their jobs ${ }^{13}$ and, presumably others must change occupation as a result of increased disability. The excess of MS deaths among males in the skilled (non-manual) class IIIN group provides support for this hypothesis, as does the lack of a similar excess among class IIIN women, whose social class is determined by their husband's occupation and not their own. Similarly, if some nurses with MS gave up their jobs or switched to physically less demanding work as a result of illness, then the occupation listed on death certificates may be an underestimate of the true prevalence of MS among nurses. There is, however, no direct evidence to support this hypothesis; it would not apply to the prospective study of British doctors and any bias introduced is likely to be small. Thus from our findings it seems unlikely that nurses or doctors should be at an increased risk of developing MS, in the United Kingdom, or elsewhere.

The relatively high prevalence of $M S$ reported at Key West, 32 probable MS patients in a population of $45648(70 / 100000)$, may be partly due to chance and partly to the thorough search for MS patients that took place there. Intensive studies in small populations of 30000 to 60000 people, for example in Sicily, ${ }^{14}$ usually show a much higher prevalence than studies in large cities. On the other hand, it is surprising that seven nurses out of 307 resident in Key West should develop MS, although two of the seven did have a family history of the disease. There are similarities between this cluster of MS patients among the Key West nurses and the unexplained cluster of four 
patients with MS among the eignt veterinary research workers studying swayback, a disease in sheep, on Bradwell Moor in 1937-39, four of whom undoubtedly developed a disease indistinguishable from MS. ${ }^{15}$ They did not get swayback disease (preventable by giving copper to the ewe) but perhaps some other virus infection from working with sheeps' brains. It is also significant that three pathology technicians and a physiotherapist at nearby Doncaster Hospital also developed an MS-like illness at about the same time. ${ }^{15}$ Lastly, there is the wartime increase of MS on the Faroe Islands reported by Kurtzke. ${ }^{16}$

That there is an environmental factor responsible for MS is also shown by the evidence from the epidemiology of the disease, that is, the high risk among adults who move from a high to a low MS prevalence area and viceversa and the lack of such an effect among the next generation of these immigrants. ${ }^{17-19}$

In Key West and elsewhere, the small clusters of MS that have been reported ${ }^{17} 18$ add support to the hypothesis that an environmental factor, probably an infection, may be responsible. Cook et al have pointed out that canine distemper virus (CDV) infection was high on Stock Island, where many of the Key West patients lived, ${ }^{20}$ and this may be relevant. Infection in the predisposed, who may have missed a protective early childhood infection, could well be the environmental factor responsible for MS. Clusters in small inbred populations may also occur because of "founder effect" if there is a high frequency of a predisposing gene, but this would not explain the Key West cluster. Roman and Sheremata have excluded tropical spastic paraparesis (TSP) misdiagnosed as MS, as a possible explanation for the Key West cluster. ${ }^{21}$ A final possibility is that some of the Key West nurses migrated to the area after the first symptoms of MS had occurred. It is known that the incidence of MS is generally lower in warmer climates, and it is conceivable that some nurses may have hoped, or been advised, that disease progression might be slower in a hotter climate. From the histories of the Key West patients this appears to be unlikely.

To conclude, in the United Kingdom there is no evidence of an increased risk of death from multiple sclerosis among the general popula- tion of nurses and doctors and this seems likely to be so in the United States and elsewhere.

We thank Mr Selwyn Hughes, of the Medical Statistics Division of the Office of Population Censuses and Surveys, London, fo his enthusiastic help with the study. We also thank Ms Hild McLoughlin and Ms Maureen Moloney for their help with the tables and preparation of the report. This study was supported by a grant from the National Multiple Sclerosis Society, New York.

1 Sheremata WA, Poskanzer DC, Witham DG, et al. Unusual occurrence on a tropical island of multiple sclerosis. occurrence on a t
Lancet $1985 ;$ ii: 618 .

2 The Miami Herald. MS in Key's search for mystery infection. Miami, Florida: November 1985.

3 O'Malley F, Dean G, Elian M. Multiple sclerosis and motor neurone disease: survival and how certified at death. JEpid Commun Hlth 1987;41:14-17.

4 Office of Population Censuses and Surveys. Death by AgeGroup and Social Class, England, Wales 1970-72 and Great Britain 1979, 80, 82, 83. London: HMSO.

5 Office of Population Censuses and Surveys. Deaths by Occupation, England and Wales, 1979, 80, 82, 83. London: HMSO.

6 Office of Population Censuses and Surveys. Deaths by Occupation, Scotland, 1979, 80, 82, 83. London: HMSO.

7 Doll R, Peto R. Mortality in relation to smoking: 20 years' observations on male British doctors. Br Med J 1976; ii: $1525-36$.

8 Doll R, Gray R, Hafner B, Peto R. Mortality in relation to smoking: 22 years' observations on female British doctors, Br Med J 1980;280:967-71.

9 Morris J, Gardner MJ. Calculating confidence intervals for relative risks (odds ratios) and standardised ratios and rates. Br Med J 1988;296:1313-6.

10 The Registrar General's statistical review of England and Wales for the year 1965. Part I, Tables, Medical. HMSO London 1967.

11 Office of Population Censuses and Surveys. Mortality Statistics. Review of the Registrar General on deaths in England and Wales 1975. (Series DH1 2). London: HMSO.

12 Office of Population Censuses and Surveys. Mortality Statistics, Cause. Review of the Registrar General on deaths by cause, sex and age, in England and Wales 1985 . (Series DH2 12). London: HMSO.

13 Ritter G, Elias W, Wilstrom J, Poser S. Zur sozialen und medizinischen Lage MS-Kranker an Hand einer epidemiologischen Studie. Rehabilitation-(Stutts) 1978; 17-2:108-15.

14 Dean G, Grimaldi G, Kelly R, Karhausen L. Multiple sclerosis in Southern Europe I: prevalence in Sicily in 1975. J Epid Commun Hlth 1979;33:107-10.

15 Dean G, McDougall EI, Elian M. Multiple sclerosis in research workers studying swayback in lambs: an updated report. J Neurol Neurosurg Psychiatry 1985;48:859-65.

16 Kurtzke JF, Hyllested K. Multiple sclerosis: an epidemic in the Faroes. Trans Am Neurol Assoc 1975;100:213-5.

17 Dean G. Annual incidence, prevalence and mortality of multiple sclerosis in white South African-born and in white immigrants to South Africa. Br Med J 1967;ii: 724-30.

18 Elian M, Dean G. Multiple sclerosis among the UK-born children of West Indian immigrants. $J$ Neurol Neurosurg Psychiatry 1987;50:327-32.

19 Elian M, Nightingale S, Dean G. Multiple sclerosis among United Kingdom-born children of immigrants from the Indian subcontinent, Africa and the West Indies. $J$ Neurol Neurosurg Psychiatry 1990;53:906-11.

20 Cook SD, Blumberg B, Dowling PC, et al. Multiple sclerosis and canine distemper on Key West, Florida. Lancet 1987; i: 1426 .

21 Roman GC, Sheremata WA. Multiple sclerosis (not tropical spastic paraparesis) on Key West, Florida, Lancet 1987;i:1199. 